\title{
Cucurbits powdery mildew race identity and reaction of melon genotypes ${ }^{1}$
}

\author{
Hudson de Oliveira Rabelo², Lucas da Silva Santos², \\ Guilherme Matos Martins Diniz², Marcus Vinicius Marin², Leila Trevisan Braz², James Donald McCreight ${ }^{3}$
}

\section{ABSTRACT}

Genetic resistance is one of the most suitable strategies to control cucurbit powdery mildew (CPM) on melon, incited by Podosphaera xanthii or Golovinomyces orontii. However, many races of these pathogens have been reported worldwide in recent years, what may compromise the effectiveness of this method. Thus, annual surveys of CPM races and the screening of germplasm for new sources of genetic resistance provide a vital support to melon breeding programs. This study aimed at identifying a natural population of CPM race under greenhouse conditions, as well as evaluating the reaction of local and exotic melon germplasm for CPM-resistance. CPM race identity was based on the reaction of eight race differentials: Védrantais, Nantais Oblong, PMR 45, PMR 5, WMR 29, Edisto 47, PI 414723 and PI 124111. Fifty-nine melon genotypes were evaluated, 53 of them being germplasm accessions, and six net melon elite-inbred lines, besides two net melon-type cultivars (Louis and Fantasy). Plants were evaluated using a visual scale for leaf lesions. The causal pathogen was confirmed to be P. xanthii, based on the presence of fibrosin bodies in conidia and the complete resistance response of winter melon (Benincasa hispida). Race 4 was identified for the first time in the São Paulo state, Brazil. Genotypes A19, A30, A32, C67, C384, JAB-3, JAB-7, JAB-9, JAB-11, JAB-18, JAB-20 and Solarking showed to be resistant to the race 4 .

KEYWORDS: Cucumis melo; Podosphaera xanthii; genetic resistance; physiologic races.

\section{INTRODUCTION}

Melon (Cucumis melo) is grown and consumed worldwide, and its production increased from 1991 through 2013 (FAO 2016). The total world production in 2013 was estimated at 29,499,542 t, of which $48.60 \%$ was produced by China. Brazil is the 11th largest producer of melon in the world,

\section{RESUMO}

Identificação de raças de oídio das cucurbitáceas e reação de genótipos de meloeiro

O uso de resistência genética é um dos métodos mais adequados para o controle de oídio das cucurbitáceas em melão, causado por Podosphaera xanthii ou Golovinomyces orontii. Contudo, muitas raças desses patógenos têm sido descobertas, o que pode comprometer a eficácia desse método. Fazem-se, então, necessários o constante monitoramento de raças de oídio e a busca por novas fontes de resistência. Objetivou-se identificar em nível de raça uma população natural de oídio das cucurbitáceas em casade-vegetação, bem como avaliar a reação de genótipos locais e exóticos de meloeiro à raça identificada. A identificação da raça foi baseada na reação de oito linhagens diferenciadoras (PI 414723, PMR 45, PMR 5, WMR 29, Edisto 47, Nantais Oblong, PI 124111 e Védrantais). Foram avaliados 59 genótipos de meloeiro, sendo 53 destes acessos de germoplasma e seis linhagens de melão rendilhado, além de duas cultivares (Louis e Fantasy). As plantas foram avaliadas com base em escala visual para lesões nas folhas. A espécie $P$. xanthii foi confirmada como o agente causal, pela visualização de corpos de fibrosina nos conídios e pela resistência da abóbora d'água (Benincasa hispida). A raça 4 foi identificada pela primeira vez no estado de São Paulo. Os genótipos A19, A30, A32, C67, C384, JAB-3, JAB-7, JAB-9, JAB-11, JAB-18, JAB-20 e Solarking mostraram-se resistentes à raça 4.

PALAVRAS-CHAVE: Cucumis melo; Podosphaera xanthii; resistência genética; raças fisiológicas.

being the first one in South America. In 2013, Brazil produced 565,900 t of melon, from which $33.82 \%$ were exported (Seagri 2016).

New production techniques contributed to increased melon production fields and higher yield, for example, by extending the growing seasons in some areas. Intensified cultivation systems have also contributed to the higher occurrence of pests and

1. Manuscript received in Sep./2017 and accepted for publication in Dec./2017 (http://dx.doi.org/10.1590/1983-40632017v4749537).

2. Universidade Estadual Paulista "Júlio de Mesquita Filho", Faculdade de Ciências Agrárias e Veterinárias, Departamento de Produção Vegetal, Jaboticabal, SP, Brasil.E-mails: hudsonorabelo@gmail.com, lucasmelhorista@gmail.com, guilhermemdiniz@hotmail.com,marcusvmarin@gmail.com, leilatb@fcav.unesp.br.

3. United States Department of Agriculture, Agricultural Research Service, U.S. Agricultural Research Station, Salinas, CA, USA.E-mail: jim.mccreight@ars.usda.gov. 
diseases that may require the use of more pesticides. Among the diseases that affect cucurbits, powdery mildew (CPM) causes a significant damage in melon and occurs worldwide (McGrath 2017).

Powdery mildew is one of the most prevalent and aggressive diseases that affect leaves in cucurbits (McGrath 2017). The infection is evident by the development of white mycelia and conidia, mainly on leaves and stems, but it can also affect fruits and floral structures. Severely infected leaves may become chlorotic, or even necrotic and brittle. Consequently, it decreases the photosynthetic potential, and concomitantly lower the fruit quality and yield (Stadnik \& Bettiol 2001).

Podosphaera xanthii [syn. Sphaerotheca fuliginea (Schlecht) Pollacci] and Golovinomyces orontii (syn. Erysiphe cichoracearum DC. Ex Mérat) are the most important CPM pathogen species of cucurbits (Kuzuya et al. 2006). P. xanthii occurs in a higher frequency in tropical and subtropical regions, whereas $G$. orontii is most observed in temperate climate (Cohen et al. 2004, Naruzawa et al. 2011). Physiological races and pathotypes are well documented for both species (Lebeda et al. 2016). There are nearly 50 identified physiological races and approximately 36 sources of host plant resistance in melon (McCreight 2006, McCreight et al. 2012).

In Brazil, $P$. xanthii races 1 and 2 are the most widespread. The first report of race 1 in Brazilian fields was made by Reifschneider et al. (1985). Race 2 was first identified in Brazil in 2000, in the São Paulo state (Kobori et al. 2002), and later in Distrito Federal (Reis \& Buso 2004), followed by the Pernambuco (Kobori et al. 2005) and Rio Grande do Norte states (Fazza 2005). Races 1, 2, 3 and 4 were identified in Northeastern Brazil by Reis et al. (2005).

The chemical control of CPM may be ineffective due to development of resistance (insensitivity) ofCPM to some fungicides (McGrath \& Shishkoff 2003, McGrath 2006, Sedláková \& Lebeda 2008). In light of the high cost of pesticides and their negative effects on the environment and human health, the most appropriate alternative for disease control is the use of resistant cultivars (Miedaner \& Flath 2007).

Though there are many physiological races of CPM worldwide, breeding programs should focus on the development of CPM-resistant cultivars to races that historically occur in the regions where the cultivars will be recommended. The local population can be initially characterized and subsequently monitored by assaying relevant CPM samples on sets of melon race differentials (Thomas et al. 1984, McCreight et al. 2012, Lebeda et al. 2016). As the CPM population shifts for virulence factors, breeders and pathologists must seek new sources of resistance for development of new CPM-resistant cultivars.

The Faculty of Agrarian and Veterinarian Sciences of the Universidade Estadual Paulista "Júlio de Mesquita Filho" (UNESP-FCAV) has a working collection of cucurbit germplasm and has developed melon-inbred lines with high fruit quality and yield (Vargas et al. 2010). There is, however, no information about the reaction of such genotypes to CPM. Assessment of the working collection may contribute to the identification and characterization of CPM-resistant genotypes in support of breeding programs that include CPM resistance in their objectives. Here we report the identification of naturally occurring CPM population in the São Paulo state, Brazil, as well as the reactions of 61 melon UNESP-FCAV accessions to the same local strain.

\section{MATERIAL AND METHODS}

The experiment was carried out in a greenhouse naturally infected with powdery mildew, at the Department of Vegetable Crops and Aromatic-Medicinal Plants of the UNESP-FCAV, in Jaboticabal, São Paulo state, Brazil ( $21^{\circ} 15^{\prime} 22^{\prime}$ 'S, $48^{\circ} 18^{\prime} 58^{\prime \prime} \mathrm{W}$ and $595 \mathrm{~m}$ of altitude). The experiment was conducted from 17 March to 2 June 2015.

Fifty-nine melon accessions from the UNESPFCAV Cucurbit Work Collection were evaluated. Most of the accessions in the collection were obtained from other institutions, such as Empresa Brasileira de Pesquisa Agropecuária (Embrapa) and Universidade Federal Rural do Semiárido (Ufersa). Six net-melon inbred lines developed by the UNESP-FCAV and two net-type hybrid cultivars (Louis and Fantasy) were included. The two hybrids are widely grown by farmers in greenhouses in Brazil.

Eight CPM race differentials were included for determination of the race present in the test: Védrantais, Nantais Oblong, PMR 45, PMR 5, WMR 29, Edisto 47, PI 414723 and PI 124111. Winter melon (Benincasa hispida) was included for verification of the species identification, as it is resistant to $P$. xanthii and susceptible to $G$. orontii (Tomason \& Gibson 2006). 
The 70 genotypes were sown in 128-cell polystyrene trays containing Bioplant ${ }^{\circledR}$ substrate. Seedlings were transplanted on 14 April 2015, at their first fully expanded leaf stage, to plastic pots of $7 \mathrm{dm}^{3}$ filled with a mixture of soil, sand and cattle manure, in a 3:1:1 proportion, respectively.

Plots were arranged in a randomized complete block design, with three replications, two plants per plot and one plant per pot, totaling six plants per genotype. The pots were set in $1.2 \mathrm{~m} \mathrm{x} 0.5 \mathrm{~m} \times 0.5 \mathrm{~m}$ double spacing: $1.2 \mathrm{~m}$ between espaliers, two rows of pots per espalier, spaced at $0.5 \mathrm{~m}$, and $0.5 \mathrm{~m}$ between pots in the same row.

A single stem per plant was trained on espaliers built with three galvanized wires, and pinched at $2.0 \mathrm{~m}$ height. Lateral branches were cut away from the main stem up to $40 \mathrm{~cm}$ above pots. Drip irrigation was used to supply water and nutritional needs via nutritive solution (Castellane \& Araújo 1995).

Prior to the test, the CPM-susceptible Nantais Oblong was grown in the same greenhouse, to increase the natural population of CPM. This cultivar was susceptible to powdery mildew in previous experiments at the same greenhouse. Infected plants of Nantais Oblong were interspersed among the experimental blocks. Seven-days after transplanting, CPM inoculum consisting of conidia and mycelia were collected from infected leaves of Nantais Oblong and inoculated on the third fully-expanded leaf of each plant, on two spots on the leaf surface, both placed at each side of and equidistant from the main leaf vein. Inoculum was transferred en masse to each spot using a disinfected paint brush.

The powdery mildew infection severity (disease reaction) was evaluated on the inoculated leaves (42 days post-inoculation), using the $0-4$ scale proposed by Lebeda \& Kř́istková (1994): 0: leaves without any visible infection; $1:<25 \%$ of foliar area covered by powdery mildew colonies showing moderate mycelial growth and weak sporulation; 2: $25-50 \%$ of foliar area covered by colonies showing weak sporulation; $3: 51-75 \%$ of foliar area covered by colonies, strong mycelial development and sporulation; $4:>75 \%$ of foliar area covered by colonies and sporulation.

$P$. xanthii was confirmed as the CPM causal agent by the presence of fibrosin bodies in conidia (Ramos et al. 2012), with the aid of a microscope. The P. xanthii physiological race was determined based on reactions of the powdery mildew differentials: Nantais Oblong and Védrantais (both resistant to race 0 ), PMR 45 (resistant to races 0 and 1), PMR 5 (resistant to races 0,1 and 2), WMR 29 (resistant to races 0,1 and $2 \mathrm{~F}$; heterogeneous reaction to race 2US; susceptible to races 4 and 5), Edisto 47 (susceptible to races 2US and 5), PI 414723 (resistant to races $0,1,2 \mathrm{~F}, 3,4$, and 5 ; susceptible to race $2 \mathrm{US}$ ) and PI 124111 (resistant to races 0, 1, 2F, 2US, 3, 4, and 5, i.e., resistant to all races reported to date in Brazil) (Table 1). McCreight (2006) stated that the heterogeneous reaction was an atypical response, on which some plants of the same plant differential are resistant and, at the meantime, others are susceptible. WMR 29 segregated 1 resistant to 3 susceptible to race 2US (McCreight et al. 1987).

The average severity score of the two plants in each plot was used for statistical analysis. Data were submitted to analysis of variance by the $F$ test and means clustering the Scott-Knott method, using the Genes ${ }^{\circledR}$ statistical software (Cruz 2006). The summary disease reaction for each genotype was either resistant (mean severity score $<2.0$ )

Table 1. Summary of disease reactions to melon powdery mildew race differentials from eight physiological races of Podosphaera xanthii [adapted from Stadnik \& Bettiol (2001) and McCreight et al. (2012)].

\begin{tabular}{|c|c|c|c|c|c|c|c|c|}
\hline \multirow{2}{*}{ Differential } & \multicolumn{8}{|c|}{ Podosphaera xanthii race } \\
\hline & 0 & 1 & $2 \mathrm{~F}$ & $2 \mathrm{US}$ & 3 & 4 & 5 & 3.5 \\
\hline Védrantais & $\mathrm{R}^{*}$ & $\mathrm{~S}$ & $\mathrm{~S}$ & $\mathrm{~S}$ & $\mathrm{~S}$ & $\mathrm{~S}$ & $\mathrm{~S}$ & $\mathrm{~S}$ \\
\hline Nantais Oblong & $\mathrm{R}$ & $\mathrm{S}$ & S & S & $\mathrm{S}$ & $\mathrm{S}$ & $\mathrm{S}$ & $\mathrm{S}$ \\
\hline PMR 45 & $\mathrm{R}$ & $\mathrm{R}$ & $\mathrm{S}$ & $\mathrm{S}$ & $\mathrm{S}$ & $\mathrm{S}$ & $\mathrm{S}$ & $\mathrm{S}$ \\
\hline PMR 5 & $\mathrm{R}$ & $\mathrm{R}$ & $\mathrm{R}$ & $\mathrm{R}$ & $\mathrm{S}$ & $\mathrm{R}$ & $\mathrm{R}$ & $\mathrm{S}$ \\
\hline WMR 29 & $\mathrm{R}$ & $\mathrm{R}$ & $\mathrm{R}$ & $\mathrm{H}$ & $\mathrm{R}$ & $\mathrm{S}$ & $\mathrm{S}$ & $\mathrm{S}$ \\
\hline Edisto 47 & $\mathrm{R}$ & $\mathrm{R}$ & $\mathrm{R}$ & S & $\mathrm{R}$ & $\mathrm{R}$ & $\mathrm{S}$ & $\mathrm{S}$ \\
\hline PI 414723 & $\mathrm{R}$ & $\mathrm{R}$ & $\mathrm{R}$ & S & $\mathrm{R}$ & $\mathrm{R}$ & $\mathrm{R}$ & $\mathrm{R}$ \\
\hline PI 124111 & $\mathrm{R}$ & $\mathrm{R}$ & $\mathrm{R}$ & $\mathrm{R}$ & $\mathrm{R}$ & $\mathrm{R}$ & $\mathrm{R}$ & $\mathrm{S}$ \\
\hline
\end{tabular}

$* \mathrm{R}=$ resistant; $\mathrm{S}=$ susceptible; $\mathrm{H}=$ heterogeneous. 
or susceptible (mean severity score $\geq 2.00$ ), per Lebeda \& Kř́stková (1994).

\section{RESULTS AND DISCUSSION}

The species identity of the CPM pathogen present in the greenhouse test was confirmed by the resistant reaction of winter melon, which had an average disease reaction of zero. Tomason \& Gibson (2006) studied the reactions of cucurbits species to $P$. xanthii and G. orontii and concluded that B. hispida genotypes are colonized only by $G$. orontii.

Differences in average disease reaction among the eight race differentials were significant $(\mathrm{p}<0.00$; Table 2). There was abundant and uniform mycelial growth and sporulation on Nantais Oblong and Véndrantais, as expected, based on the previous infection of Nantais Oblong in the greenhouse. There was also abundant infection on PMR 45 and WMR 29, while PMR 5, Edisto 47, PI 414723 and PI 12411 exhibited a high-level resistance (Table 2). The summary reaction pattern of the differentials in this test was identical to that for P. xanthii race 4 (Table 1). This is the first report of race 4 in the São Paulo state, Brazil. Race 4 was previously found in Northeastern Brazil (Reis et al. 2005). Fazza (2006) identified the races 1 and 2 in the São Paulo state, but the race differentials used in his study were limited to Hale's Best Jumbo, Véndrantais, PMR 45 and PMR 6. These differentials could only discern races $0,1,2$ and 3 . Race 4 may have been present at that time, but not identified, due to the limited resolving power of the race differentials.

CPM race identification tests have been performed with whole plants in greenhouses, growth

Table 2. Average disease reactions and classification of eight powdery mildew race differentials to Podosphaera xanthii in a greenhouse.

\begin{tabular}{lcc}
\hline \multicolumn{1}{c}{ Differential } & $\begin{array}{c}\text { Average } \\
\text { disease reaction }\end{array}$ & $\begin{array}{c}\text { Reaction } \\
\text { classification }\end{array}$ \\
\hline Védrantais & 4.00 & $\mathrm{~S}$ \\
Nantais Oblong & 4.00 & $\mathrm{~S}$ \\
PMR 45 & 3.33 & $\mathrm{~S}$ \\
PMR 5 & 0.00 & $\mathrm{R}$ \\
WMR 29 & 3.67 & $\mathrm{~S}$ \\
Edisto 47 & 0.00 & $\mathrm{R}$ \\
PI 414723 & 0.67 & $\mathrm{R}$ \\
PI 124111 & 0.70 & $\mathrm{R}$ \\
\hline Race identified & \multicolumn{2}{|}{} \\
\hline
\end{tabular}

chambers and fields, and with leaf discs (Lebeda et al. 2016). Such tests have employed different means of inoculation. For example, Reis \& Buso (2004) identified race 2 using PMR 45, PMR 6 and Hale's Best Jumbo grown in a greenhouse and inoculated with a conidial suspension with $1 \times 10^{5}$ conidia $\mathrm{mL}^{-1}$. In contrast, McCreight \& Coffey (2011) used Iran H, Védrantais, Top Mark, PMR 45, PMR 5, WMR 29, Edisto 47, PI 414723, MR-1, PI 124111, PI 124112 and PI 313970 as differentials to identify the occurrence of a new race of $P$. xanthii, named race $\mathrm{S}$, in a naturally infected experimental field located at Holtville, California, USA. PI 313970 was the only resistant genotype when evaluated at 51 days after sowing, at fruiting onset.

The criteria to identify or discern CPM races has changed considerably since the 1930 s, when race 2 was identified on PMR 45 (Jagger et al. 1938). Only two differentials were known for 40 years: PMR 45 (resistant to race 1) and PMR 5 (resistant to races 1 and 2). Race 3 appeared in the fall of 1976 on PI 321005 (Tainan \#2), which was reported to be resistant to $P$. xanthii race 2 (Sowell \& Corley 1974). The occurrence of a new race was confirmed in 1977 , when PMR 45, PMR 5 and PMR 6 were infected (Thomas 1978). Thus, one could discern three races with two appropriately selected genotypes.

Variations of the commonly used set of differentials described by Thomas et al. (1984) to identify races 1, 2 and 3, based on the reaction of Hale's Best Jumbo, PMR 45, PMR 6 and PMR 5, are no longer sufficient to fully characterize CPM isolates in light of the high number of races described to date (McCreight 2006, McCreight et al. 2012).

A set of 21 melon CPM differentials has been proposed for characterization of virulence variation in P. xanthii and G. orontii (Lebeda et al. 2016). This large set is ideal for detection of a new variation in a pathogen population, but is not necessary for detection of a new and unexpected virulence variation in a melon production area. The set of melon CPM differential used in this study will discern $P$. xanthii races 1,2 (and its variants), 3, 4, 5 and 3.5, being the latter two races the most widely reported in the country (Table 1). If these are all found susceptible, then the others in the set of 21 differentials may be challenged to further characterize the variant strain and identify a potential source of resistance.

Differences among the 61 melon genotypes and CPM differentials for average disease reaction 
were significant $(\mathrm{p}<0.01)$ (Table 3). The coefficient of variation $(15.76 \%)$, without data transformation, is satisfactory and gives confidence to the results. The Scott-Knott test effectively separated the susceptible and resistant genotypes, although it identified subgroups as well. Those subdivisions may indicate intermediate levels of resistance and could be used to select moderately-resistant plants, though most powdery mildew resistance research has been based only on binary reactions (resistant and susceptible).

Thirteen of the 61 accessions from germplasms were resistant to $P$. xanthii race 4 , with average severity scores ranging from 0.0 to 1.8 (Table 3 ). Six lines developed by the UNESP-FCAV (JAB-3, JAB-7, JAB-9, JAB-11, JAB-18 and JAB-20) showed high levels of resistance, evidenced by no or limited mycelial development. Inheritance of resistance in these lines remains to be determined. If resistance to race 4 in these lines is dominant or codominant, they could be used for making $\mathrm{F}_{1}$ hybrids. Resistant genotypes were shown to have high complementarity and high specific combining ability (SCA), more specifically when JAB-11 is crossed with JAB-20 (Vargas et al. 2010). If resistance to race 4 is, however,

Table 3. Disease reactions of 69 melon genotypes and Benincasa hispida to Podosphaera xanthii race 4.

\begin{tabular}{|c|c|c|c|c|c|}
\hline Genotype & Mean $^{1}$ & Reaction $^{2}$ & Genotype & Mean $^{1}$ & Reaction $^{2}$ \\
\hline A11 & $4.0 \mathrm{a}$ & $\mathrm{S}$ & PI 180280 & $3.8 \mathrm{a}$ & $\mathrm{S}$ \\
\hline A12 & $4.0 \mathrm{a}$ & S & Caroline & $3.8 \mathrm{a}$ & S \\
\hline A23 & $4.0 \mathrm{a}$ & $\mathrm{S}$ & $\mathrm{C} 47$ & $3.7 \mathrm{a}$ & S \\
\hline $\mathrm{C} 160$ & $4.0 \mathrm{a}$ & $\mathrm{S}$ & Melão Gaúcho & $3.7 \mathrm{a}$ & S \\
\hline $\mathrm{C} 163$ & $4.0 \mathrm{a}$ & $\mathrm{S}$ & WMR 29 & $3.7 \mathrm{a}$ & S \\
\hline $\mathrm{C} 180$ & $4.0 \mathrm{a}$ & $\mathrm{S}$ & A17 & $3.5 \mathrm{a}$ & S \\
\hline C189 & $4.0 \mathrm{a}$ & $\mathrm{S}$ & $\mathrm{C} 190$ & $3.5 \mathrm{a}$ & S \\
\hline C246 & $4.0 \mathrm{a}$ & S & $\mathrm{C} 327$ & $3.5 \mathrm{a}$ & S \\
\hline $\mathrm{C} 265$ & $4.0 \mathrm{a}$ & $\mathrm{S}$ & A13 & $3.3 \mathrm{~b}$ & S \\
\hline $\mathrm{C} 272$ & $4.0 \mathrm{a}$ & $\mathrm{S}$ & PMR 45 & $3.3 \mathrm{~b}$ & S \\
\hline C329 & $4.0 \mathrm{a}$ & S & A28 & $3.2 \mathrm{~b}$ & S \\
\hline C359 & $4.0 \mathrm{a}$ & $\mathrm{S}$ & A25 & $3.0 \mathrm{~b}$ & S \\
\hline C68 & $4.0 \mathrm{a}$ & $\mathrm{S}$ & Pepino de Neve & $3.0 \mathrm{~b}$ & S \\
\hline C70 & $4.0 \mathrm{a}$ & $\mathrm{S}$ & A14 & $2.7 \mathrm{c}$ & $\mathrm{S}$ \\
\hline C71 & $4.0 \mathrm{a}$ & $\mathrm{S}$ & PI 164320 & $2.5 \mathrm{c}$ & $\mathrm{S}$ \\
\hline C88 & $4.0 \mathrm{a}$ & $\mathrm{S}$ & PI 179680 & $2.3 \mathrm{c}$ & S \\
\hline Flexuosus "M-2791" & $4.0 \mathrm{a}$ & $\mathrm{S}$ & PI 482398 & $2.2 \mathrm{c}$ & S \\
\hline PI 420149 & $4.0 \mathrm{a}$ & $\mathrm{S}$ & A19 & $1.8 \mathrm{~d}$ & $\mathrm{R}$ \\
\hline PI 420150 & $4.0 \mathrm{a}$ & $\mathrm{S}$ & A32 & $0.7 \mathrm{e}$ & $\mathrm{R}$ \\
\hline PI 532830 & $4.0 \mathrm{a}$ & $\mathrm{S}$ & Solarking & $0.7 \mathrm{e}$ & $\mathrm{R}$ \\
\hline Védrantais & $4.0 \mathrm{a}$ & $\mathrm{S}$ & PI 124111 & $0.7 \mathrm{e}$ & $\mathrm{R}$ \\
\hline Nantais Oblong & $4.0 \mathrm{a}$ & $\mathrm{S}$ & PI 414723 & $0.7 \mathrm{e}$ & $\mathrm{R}$ \\
\hline PI 224769 & $4.0 \mathrm{a}$ & $\mathrm{S}$ & A30 & $0.3 \mathrm{f}$ & $\mathrm{R}$ \\
\hline PI 183256 & $4.0 \mathrm{a}$ & $\mathrm{S}$ & JAB-11 & $0.2 \mathrm{f}$ & $\mathrm{R}$ \\
\hline Melão verdadeiro & $4.0 \mathrm{a}$ & $\mathrm{S}$ & JAB-20 & $0.2 \mathrm{f}$ & $\mathrm{R}$ \\
\hline Mi Tang Ting & $4.0 \mathrm{a}$ & $\mathrm{S}$ & Perlita & $0.0 \mathrm{f}$ & $\mathrm{R}$ \\
\hline Irene & $4.0 \mathrm{a}$ & $\mathrm{S}$ & JAB-3 & $0.0 \mathrm{f}$ & $\mathrm{R}$ \\
\hline Charentais Fom 1 & $4.0 \mathrm{a}$ & $\mathrm{S}$ & Winter Melon & $0.0 \mathrm{f}$ & $\mathrm{R}$ \\
\hline Fantasy & $4.0 \mathrm{a}$ & $\mathrm{S}$ & JAB-7 & $0.0 \mathrm{f}$ & $\mathrm{R}$ \\
\hline Louis & $4.0 \mathrm{a}$ & $\mathrm{S}$ & C384 & $0.0 \mathrm{f}$ & $\mathrm{R}$ \\
\hline PI 157082 & $4.0 \mathrm{a}$ & $\mathrm{S}$ & C67 & $0.0 \mathrm{f}$ & $\mathrm{R}$ \\
\hline PI 420145 & $4.0 \mathrm{a}$ & S & Edisto 47 & $0.0 \mathrm{f}$ & $\mathrm{R}$ \\
\hline A24 & $3.8 \mathrm{a}$ & $\mathrm{S}$ & PMR 5 & $0.0 \mathrm{f}$ & $\mathrm{R}$ \\
\hline A29 & $3.8 \mathrm{a}$ & $\mathrm{S}$ & JAB-9 & $0.0 \mathrm{f}$ & $\mathrm{R}$ \\
\hline C194 & $3.8 \mathrm{a}$ & $\mathrm{S}$ & JAB-18 & $0.0 \mathrm{f}$ & $\mathrm{R}$ \\
\hline $\mathrm{F}$ test & $37.56^{* *}$ & & & & \\
\hline Mean & 2.85 & & & & \\
\hline $\mathrm{CV}(\%)$ & 15.76 & & & & \\
\hline
\end{tabular}

${ }^{1}$ Averages followed by the same letter do not differ significantly at $\mathrm{p}<0.01$, by the Scott-Knott test; ${ }^{2} \mathrm{R}=$ resistant and $\mathrm{S}=$ susceptible; $* *$ significant at $\mathrm{p}<0.01$. 
recessive, race 4-resistant open-pollinated cultivars or inbred lines suitable as parents for producing resistant $\mathrm{F}_{1}$ hybrids will have to be developed.

This is the first report of resistance to P. xanthii race 4 in Perlita, an orange flesh, western US shipping type melon adapted to the lower Rio Grande area of Texas (Texas University 1964). Perlita is also resistant to races 1 and 2 (Harwood \& Markarian 1968, McCreight 2006, Robinson 2010).

Accessions A19, A30 and A32 were resistant to race 4 . They were collected in Northeastern Brazil (Torres Filho et al. 2009). As they have been cultivated in that region, they could be potentially used to breed cultivars adapted to the tropical climate conditions of Northeastern Brazil.

Accessions C384 and C67 from the Embrapa Clima Temperado were resistant to race 4. C67 is cultivated in Southern Brazil (Neitzke et al. 2009) and would be a suitable race 4 resistance source for that area. C160 was highly susceptible to race 4 (Table 3). C67 and C160 are similar for 18 morphological descriptors (data not shown), but their reactions to powdery mildew race 4 were different. In the Paraná state, $P$. xanthii is more frequently reported to incite CPM than G. orontii (Aguiar et al. 2012). CPM breeding programs for that region should emphasize resistance to $P$. xanthii and $\mathrm{C} 67$ would be suitable for resistance and horticultural traits.

Forty-eight of the 61 accessions were susceptible to race 4 , with average disease severity reactions ranging from 2.2 to 4.0 (Table 3). Hybrids Louis and Fantasy, described as resistant to $P$. xanthii (Takii Seeds 2016a and 2016b), were highly susceptible to race 4 . These results emphasize the need to determine the race(s) present in production areas, in order to select the most suitable cultivars for each region. For example, Santos et al. (2004) reported three of 20 melon $\mathrm{F}_{1}$ hybrids resistant to CPM. However, they did not identify the CPM race used in their experiment. Lack of information regarding the race could mislead a grower into making the wrong cultivar selection due to incomplete information.

Our results emphasize the need of constant monitoring of cucurbit powdery mildew races (Thomas et al. 1984, Cohen et al. 2004). For that, the eight CPM race differentials used in this study (Table 1) are sufficient to identify the most commonly reported races of $P$. xanthii. The 10 resistant accessions found in the set of 61 accessions are suitable donors for the development of new open-pollinated cultivars and $F_{1}$ hybrids. However, it is important to note the pending morphological characterization and studies of the inheritance of resistance.

\section{CONCLUSIONS}

1. The cucurbit powdery mildew isolated in the present study was confirmed to be caused by Podosphaera xanthii, based on presence of fibrosin bodies in the conidia and complete resistance reaction expressed by winter melon (Benincasa hispida);

2. P. xanthii race 4 was observed for the first time in the São Paulo state, Brazil;

3. Eleven regionally-adapted Brazilian melon accessions (A19, A32, A30, JAB-11, JAB-20, JAB-3, JAB-7, C384, C67, JAB-9, JAB-18), Solarking and Perlita are resistant to $P$. xanthii race 4 , as defined by a set of eight melon CPM race differentials.

\section{REFERENCES}

AGUIAR, B. M. et al. Fungal species that cause powdery mildew in greenhouse-grown cucumber and melon in Paraná State, Brazil. Acta Scientiarum, v. 34, n. 3, p. 247 252, 2012.

CASTEllane, P. D.; ARAÚJO, J. A. C. Cultivo sem solo: hidroponia. Jaboticabal: Funep, 1995.

COHEN, R. et al. Monitoring physiological races of Podosphaera xanthii (syn. Sphaerotheca fuliginea), the causal agent of powdery mildew in cucurbits: factors affecting race identification and the importance for research and commerce. Phytoparasitica, v. 32, n. 2, p. 174-183, 2004.

CRUZ, C. D. Programa Genes: análise e processamento de dados baseado em modelos biométricos e em estatística experimental. Viçosa: Ed. da UFV, 2006.

FAZZA, A. C. Caracterização e ocorrência de agentes causais de oídio em cucurbitáceas no Brasil e reação de germoplasma de meloeiro. 2006. 60 f. Dissertação (Mestrado em Fitopatologia) - Escola Superior de Agricultura “Luiz de Queiroz", Piracicaba, 2006.

FAZZA, A. C. Ocorrência da raça 2 de Podosphaera xanthii em melão em Mossoró (RN). In: CONGRESSO BRASILEIRO DE FITOPATOLOGIA, 38., 2005, Brasília, DF. Resumos... Brasília: Ed. da UnB, 2005. 1 CD-ROM.

FOOD AND AGRICULTURE ORGANIZATION OF THE UNITED NATIONS (FAO). FAOSTAT. 2016. 
Available at: <http://faostat3.fao.org/browse/Q/*/E > . Access in: Sep. 2016.

HARWOOD, R. R.; MARKARIAN, D. A genetic survey of resistance to powdery mildew in muskmelon. Journal of Heredity, v. 59, n. 3, p. 213-217, 1968.

JAGGER, I. C.; WHITAKER, T. W.; PORTER, D. R. A new biologic form of powdery mildew on muskmelons in the Imperial Valley of California. Plant Disease Reporter, v. 22, n. 22, p. 275-276, 1938.

KOBORI, R. F. et al. Ocorrência da raça 2 de Sphaerotheca fuliginea em melão no estado de São Paulo. Fitopatologia Brasileira, v. 27, n. 1, p. 123, 2002.

KOBORI, R. F. et al. Ocorrência da raça 2 de Podosphaera xanthii em melão no estado de Pernambuco. In: CONGRESSO PAULISTA DE FITOPATOLOGIA, 28., 2005, São Paulo. Resumos... Botucatu: Summa Phytopahtologica, 2005. p. 20.

KUZUYA, M. et al. Powdery mildew (Podosphaera xanthii) resistance in melon is categorized into two types based on inhibition of the infection processes. Journal of Experimental Botany, v. 57, n. 9, p. 2093-2100, 2006.

LEBEDA, A. et al. Cucurbit powdery mildews: methodology for objective determination and denomination of races. European Journal of Plant Pathology, v. 144, n. 2, p. 399-410, 2016.

LEBEDA, A.; KŘÍSTKOVÁ, E. Field resistance of cucurbita species to powdery mildew (Erysiphe cichoracearum). Zeitschrift für Pflanzenkrankheiten und Pflanzenschutz, v. 101, n. 6, p. 598-603, 1994.

McCREIGHT, J. D. et al. Powdery mildew resistance genes in muskmelon. Journal of the American Society for Horticultural Science, v. 112, n. 1, p. 156-160, 1987.

McCREIGHT, J. D. et al. Cucurbit powdery mildew of melon incited by Podosphaera xanthii: global and western US perspectives. In: EUCARPIA MEETING ON GENETICS AND BREEDING OF CUCURBITACEAE, 10., 2012, Antalya. Proceedings... Antalaya: University of Cukurova, 2012. p. 181-189.

McCREIGHT, J. D. Melon-powdery mildew interactions reveal variation in melon cultigens and Podosphaera xanthii races 1 and 2. Journal of the American Society for Horticultural Science, v. 131, n. 1, p. 59-65, 2006.

McCREIGHT, J. D.; COFFEY, M. D. Inheritance of resistance in melon PI 313970 to cucurbit powdery mildew incited by Podosphaera xanthii race S. HortScience, v. 46, n. 6, p. 838-840, 2011.

McGRATH, M. Occurrence of fungicide resistance in Podosphaera xanthii and impact on controlling cucurbit powdery mildew in New York. In: CUCURBITACEAE
2006, Asheville. Proceedings... Asheville: Universal Press, 2006. p. 473-482.

McGRATH, M. T. Powdery mildew. In: KEINATH, A. P.; WINTERMANTEL, W. M.; ZITTER, T. A. (Eds.). Compendium of cucurbit diseases and insect pests. 2. ed. St. Paul: APS Press, 2017. p. 62-64.

McGRATH, M. T.; SHISHKOFF, N. First report of the cucurbit powdery mildew fungus (Podosphaera xanthii) resistant to strobilurin fungicides in the United States. Plant Disease, v. 87, n. 8, p. 1007-1007, 2003.

MIEDANER, T.; FLATH, K. Effectiveness and environmental stability of quantitative powdery mildew (Blumeria graminis) resistance among winter wheat cultivars. Plant breeding, v. 126, n. 6, p. 553-558, 2007.

NARUZAWA, E. S. et al. Estudo da diversidade genética de Podosphaera xanthii através de marcadores AFLP e sequências ITS. Summa Phytopathologica, v. 37, n. 2, p. 94-100, 2011.

NEITZKE, R. S. et al. Caracterização morfológica e dissimilaridade genética entre variedades crioulas de melão. Horticultura Brasileira, v. 27, n. 4, p. 534-538, 2009.

RAMOS, C. B. et al. Podosphaera xanthii but not Golovinomyces cichoracearum infects cucurbits in a greenhouse at Salinas, California. Cucurbit Genetics Cooperative Report, v. 33, n. 1, p. 33-34, 2012.

REIFSCHNEIDER, F. J. B. et al. Powdery mildew of melon (Cucumis melo) caused by Sphaerotheca fuliginea in Brazil. Plant Disease, v. 69, n. 12, p. 1069-1070, 1985.

REIS, A. et al. Caracterização do perfil patogênico de isolados de Podosphaera xanthii obtidos em cucurbitáceas na região Nordeste do Brasil. Horticultura Brasileira, v. 23, n. 2, p. 362-366, 2005.

REIS, A.; BUSO, J. A. Levantamento preliminar de raças de Sphaerotheca fuliginea no Brasil. Horticultura Brasileira, v. 22, n. 3, p. 628-631, 2004.

ROBINSON, R. W. Powdery mildew resistance of cucurbits at different locations. Cucurbit Genetics Cooperative Report, v. 33-34, n. 1, p. 22-23, 2010.

SANTOS, A. A. et al. Avaliação de híbridos de melão quanto às principais doenças nos estados do Ceará e Rio Grande do Norte. Fortaleza: Embrapa Agroindústria Tropical, 2004.

SECRETARIA DE AGRICULTURA, PECUÁRIA, IRRIGAÇÃO, PESCA E AQUICULTURA (Seagri). Exportações de frutas crescem 6,2\% em 2013. 2016. Available at: <http://www.seagri.ba.gov.br/ 
noticias/2014/01/21/exporta $\% \mathrm{C} 3 \% \mathrm{~A} 7 \% \mathrm{C} 3 \% \mathrm{~B} 5$ es-defrutas-crescem-62-em-2013>. Access in: Sep. 2016.

SEDLÁKOVÁ, B.; LEBEDA, A. Fungicide resistance in Czech populations of cucurbit powdery mildews. Phytoparasitica, v. 36, n. 3, p. 272-289, 2008.

SOWELL, G. J.; CORLEY, W. L. PI 321005 (Tainan \#2), a high-quality source of resistance to three cantaloup diseases. Plant Disease Reporter, v. 58, n. 10, p. 899-902, 1974.

STADNIK, M. J.; BETTIOL, W. Oídios de cucurbitáceas. In: STADNIK, M. J.; KOBORI, R. F.; RIVERA, M. C. Oídios. Jaguariuna: Embrapa Meio Ambiente, 2001.

TAKII SEEDS. Melão híbrido Louis. 2016a. Available at: <http://www.takii.com.br/melaolouis.html $>$. Access in: Mar. 2016.

TAKII SEEDS. Melão híbrido Fantasy. 2016b. Available at: $<$ http://www.takii.com.br/melaofantasy.html $>$. Access in: Mar. 2016.
TEXAS UNIVERSITY. Perlita cantaloupe. College Station: Texas University, 1964.

THOMAS, C. E. et al. The importance of monitoring races of powdery mildew on muskmelon. Cucurbit Genetics Cooperative Report, v. 7, n. 1, p. 58-59, 1984.

THOMAS, C. E. A new biological race of powdery mildew [Sphaerotheca fuliginea] of cantaloups. Plant Disease Reporter, v. 62, n. 3, p. 223, 1978.

TOMASON, Y.; GIBSON, P. T. Fungal characteristics and varietal reactions of powdery mildew species on cucurbits in the steppes of Ukraine. Agronomy Research, v. 4, n. 2, p. 549-562, 2006.

TORRES FILHO, J. et al. Caracterização morfológica de acessos de meloeiro coletados no Nordeste brasileiro. Caatinga, v. 22, n. 3, p. 174-181, 2009.

VARGAS, P. F. et al. Avaliação de parentais e híbridos experimentais de melão rendilhado. Ciência e Agrotecnologia, v. 34, n. 5, p. 1102-1108, 2010. 